\title{
Silence and the right to justice: Confronting impunity in Spain
}

\author{
Abstract \\ Silence may play different roles during post-authoritarian and \\ transitional periods: in Spain, it has been a key element for impunity. \\ Silence was twice imposed to victims: first, after the end of the civil war \\ and during dictatorship, silence was a survival strategy to Franco's \\ repressive machinery; later, during the democratic transition, silence was \\ said to be the price to pay for reconciliation and democracy. While the \\ victims on Franco's side had reparation, Franco's victims did not -in fact \\ thousands of them still remain buried in unmarked mass graves. Any \\ attempts to pursue justice through the Spanish judiciary have been \\ unsuccessful, including the resort to the ECtHR. This paper analyses the \\ ways in which silence was imposed and the instrumental role the \\ repression and its normative regime had on it, and in turn the impact of \\ silence on justice. In this context, the role of silence goes beyond \\ impacting the individual trauma and shaping a national memory but also \\ makes victims unwillingly give up their right to justice. This article \\ contends that, when imposed (explicit or implicitly) silence results in \\ impunity and courts should take this into consideration when determining \\ victims' effective capacity to claim their rights in judicial fora.
}

Keywords: right to justice, transitional justice, Spain, impunity, silence 


\section{Introduction}

Although often referred to as a model of peaceful and negotiated political regime change, ${ }^{1}$ the Spanish transition to democracy is actually an experience of silence and choice to forget, which has resulted in limited rehabilitation of victims and impunity for perpetrators. For many decades, victims have lived under the veil of silence, twice imposed to them: first, after the end of the Spanish Civil War and during the dictatorship, silence was a survival strategy to Franco's repressing policies, laws and practices; later, during the democratic transition, silence became the price to pay for reconciliation and democracy.

It has only been since 2000 that the victims of the civil war and the repression that followed, and their relatives have been able to raise such veil of silence and demand truth and justice. This has been the result of a process of inquiry both at individual level regarding their own families' history- and at general level -demanding wider historical discovery and recognition of events- which was started by the generation of Spaniards that did not live through the 'pact of silence' of the transition. This mobilisation at civil society level let to the opening of a transitional justice debate and demands for institutional responses. However, whilst the claims for truth and moral restoration found some echo in the approval of the 'Historical Memory Law' and other limited measures, the door for accountability for human rights violations has remained firmly closed, thus preventing the victims to enjoy the right to justice.

${ }^{1}$ A. Gil Gil, La Justicia de Transición en España. De la Amnistía a la Memoria Histórica (Barcelona: Atelier, 2009), 21. 
Here we argue that difficulties to realize the right to justice for victims of the Spanish civil war and dictatorship are largely related to the impact of silence in the Spanish society. This article explores the elements of the right to justice as a human rights and whether they are present in the Spanish process of confronting the human rights violations of the civil war and dictatorship. The following sections provide an overview of such violations, analyse the elements of the political transition which led to the impunity that continues today and the torturous road to justice through the courts.

\section{The right to justice as a human right}

A judicial system that provides victims of human rights violations with real and effective mechanisms to get their rights protected is key to give effect to the State obligation to fulfil human rights. ${ }^{2}$ To grant this is so, international human rights instruments recognize the right to judicial protection through an effective remedy ${ }^{3}$, as well as a set of rights regarding the due process. These include the right to a fair and public hearing by a competent, independent and impartial tribunal established by law, minimum procedural rights for those charged in a criminal process, and the presumption of innocence. ${ }^{4}$

2 J. Bonet Pérez, 'La lucha contra la impunidad y sus implicaciones jurídicas internacionales para el ejercicio de la justicia transicional', in Impunidad, derechos humanos y justicia transicional, J. Bonet Pérez and R.A. Alija Fernández (Bilbao: Universidad de Deusto, 2009), 25.

${ }^{3}$ See arts. 2.3 of the International Covenant on Civil and Political Rights (ICCPR), 13 of the European Convention of Human Rights (ECHR), 25 of the American Convention on Human Rights (AmCHR), and 7 of the African Charter on Human and Peoples' Rights (AfCHPR).

${ }^{4}$ See arts. 14 ICCPR, 6 ECHR, 8 AmCHR, and 7 AfCHPR. 
When serious and gross human rights violations have been committed, the right to justice becomes critical to avoid impunity. The Updated Set of principles for the protection and promotion of human rights through action to combat impunity states that

States shall undertake prompt, thorough, independent and impartial investigations of violations of human rights and international humanitarian law and take appropriate measures in respect of the perpetrators, particularly in the area of criminal justice, by ensuring that those responsible for serious crimes under international law are prosecuted, tried and duly punished.

Although the decision to prosecute lies primarily within the competence of the State, victims, their families and heirs should be able to institute proceedings, on either an individual or a collective basis, particularly as parties civiles or as persons conducting private prosecutions in States whose law of criminal procedure recognizes these procedures. States should guarantee broad legal standing in the judicial process to any wronged party and to any person or non-governmental organization having a legitimate interest therein. ${ }^{5}$

From this approach, the right to justice therefore implies a right to access to justice, which can be generally understood as 'the right to a judicial remedy before an

${ }^{5}$ UN doc. E/CN.4/2005/102/Add.1, 8 February 2005, principle 19: Duties of States with regard to the administration of justice. 
independent court of law'. ${ }^{6}$ Although criminal proceedings are preferred, ${ }^{7}$ they may not be the only ones suitable to address gross human rights violations. Indeed, in a broader sense, the term justice can also include 'those remedies offered by competent public authorities, which are not courts of law but can nevertheless perform a dispute settlement function ${ }^{8}{ }^{8}$ In any event, it involves a right to a procedure -as Brems puts it- ${ }^{9}$ that applies

${ }^{6}$ F. Francioni, 'The Rights of Access to Justice under Customary International Law', in Access to Justice as a Human Right, ed. F. Francioni (Oxford: Oxford University Press, 2007), 4.

${ }^{7}$ The obligation to investigate and to prosecute, try and sentence particularly rises regarding violations that constitute crimes according to domestic law and/or international law, e.g. and similar cruel, inhuman and degrading treatment -Article 7 ICCPR-, summary and arbitrary killing - Article 6 ICCPR- or enforced disappearances - Articles 7 and 9, and frequently 6 , ICCPR-. See General Comment No. 31 - The Nature of the General Legal Obligation Imposed on States Parties to the Covenant, Human Rights Committee, Adopted on 29 March 2004 (2187 ${ }^{\text {th }}$ meeting), UN Doc. CCPR/C/21/Rev.1/Add. 13, para. 18.

${ }^{8}$ Francioni, 'The Rights of Access to Justice', 4. See Articles 2(3) ICCP and 13 ECHR. Concerning the Spanish case, in 2016 a civil court ordered the exhumation of several corpses buried at the so-called 'Valley of the Fallen' (Valle de los Caídos), a monumental memorial built by Franco to honour the fallen (on his side) during the Civil War and where he himself is buried (see Juzgado de Primera Instancia No. 2 of San Lorenzo de El Escorial, Auto No. 112/16, 30 March 2016). The judge adjudicated in a claim for informations ad perpetuam memoriam, a procedure formerly included in the Spanish Civil Procedure Code (Articles 2002 to 2010, derogated in 2015). The possibility to resort to administrative courts to get investigations done concerning enforced disappearances has been explored too in R.A. Alija Fernández \& E. Calvet Martínez, 'La exigibilidad en España de los derechos de las víctimas de desapariciones forzadas por vía contencioso-administrativa como alternativa a la vía penal', in Desapariciones forzadas, represión política y crímenes del franquismo, ed. C. Pérez González and R. Escudero Alday (Madrid: Trotta, 2013), 101-20.

${ }^{9}$ E. Brems, 'Procedural protection. An examination of procedural safeguards read into substantive Convention rights', in Shaping Rights in the ECHR: The Role of the European Court of Human Rights, ed. E. Brems and J. Gerards (New York: Cambridge University Press, 2013), 140. 
to investigations into alleged human rights violations and to the availability of remedies for claimed victims of human rights violations. ${ }^{10}$

More specifically, the fulfilment of the right to justice concerning serious violations of human rights requires the existence of effective remedies that -as mentioned above- provide with means to undertake -mainly ex officio but also ex parte-prompt, thorough, independent and impartial investigations, and to prosecute, try and punish the alleged perpetrators. ${ }^{11}$ The failure to conduct investigations into violations of fundamental human rights (such as summary and arbitrary executions, torture, or enforced disappearance) involves a further violation of the substantive dimension of the right to justice. ${ }^{12}$ The duty to investigate is particularly relevant when the State's responsibility for human rights violations cannot be clearly established. ${ }^{13}$ Furthermore, it limits the effect of the principle of non-retroactivity of human rights treaties regarding human rights violations committed before their entry into force, as the investigation 'is required to secure retrospectively the substantive right of the victim'. ${ }^{14}$ The refusal to investigate may also amount to torture or inhumane treatment of relatives in certain

${ }^{10}$ Ibid.

${ }^{11}$ Updated Set of principles for the protection and promotion of human rights through action to combat impunity - Report of the independent expert to update the Set of principles to combat impunity, Diane Orentlicher: Addendum, UN Doc. E/CN.4/2005/102/Add.1, 8 February 2005, principle 19 .

${ }^{12}$ See generally A. Seibert-Fohr, Prosecuting Serious Human Rights Violations (New York: Oxford University Press, 2009).

${ }^{13}$ Ibid., 129.

${ }^{14}$ Ibid. 
circumstances, particularly concerning enforced disappearances. ${ }^{15}$ Additionally, ensuring compliance with the right to justice regarding serious and gross human rights violations may also require the State to adopt restrictive measures on certain legal rules, e.g. statutory limitations or prescription, amnesties, asylum, extradition, non bis in idem, defences (such as due obedience, superior responsibility, official status), effects of legislation on disclosure or repentance, jurisdiction of military courts, and the principle of the irremovability of judges. ${ }^{16}$

Two key elements linked to the right to justice are particularly critical in times of transition: the proper functioning of the judicial system and the existence of truly effective remedies before courts regarding the violations of human rights previously committed. ${ }^{17}$ Neither of these can be attributed to the Spanish judicial system with regards to human rights violations committed during the civil war and dictatorship that followed. This is largely related to the imposition on victims of two consecutive layers of silence regarding human rights violations (under Franco's dictatorship and during the transition to democracy), which also had negative effects on their capacity to claim their rights, as we will discuss below.

\section{Civil war and dictatorship: silence and official history}

${ }^{15}$ See e.g., Human Rights Committee, Quinteros v. Uruguay, Communication No. 107/1981, 21 July 1983, para. 14; ECHR, Kurt v. Turkey, 25 May 1998, §§ 130-4, Reports of Judgments and Decisions 1998-III.

${ }^{16}$ Updated Set of principles, principles 23-30.

${ }^{17}$ Bonet Pérez, 'La lucha contra la impunidad', 26. 
On $1^{\text {st }}$ April 1939 a civil war which had lasted three years came to an end. It had commenced on $17^{\text {th }}$ July 1936 , when a military rebellion challenged the legitimate and democratically elected government. The dictatorship which followed lasted over 36 years, until the death of the dictator, General Francisco Franco, on $20^{\text {th }}$ November 1975. There is little agreement among historians about the extent of the human rights and humanitarian law violations in the Spanish civil war. Casualty figures vary between 300,000 and 400,000 dead during the three years of war. ${ }^{18}$ However, while both sides committed atrocities, the repression on Franco's side was systematic and especially cruel, particularly towards the end. As British historian Paul Preston has recorded, on the last month of the war, upon the rebel's victory, 20,000 civilians were executed and many more died of starvation and sickness in prisons, concentration and labour camps. ${ }^{19}$

In the post-war, an overt repressive apparatus and legal system was established in Spain. ${ }^{20}$ A complex normative and institutional web was articulated to dismantle the democratic republican legal system - which was branded as subversive- and establish a

${ }^{18}$ Preston provides the figures of 300,000 men dead in the war fronts and 200,000 civilian, men and women, dead far away from the front. P. Preston, El Holocausto Español. Odio y Exterminio en la Guerra Civil y Después (Madrid: Debate, 2011), 17. More conservative estimates calculate 140,000 people killed away from the battlefield during the war and first decade of the dictatorship (until 1950), see S. Juliá and others, Victimas de la Guerra Civil (Madrid: Temas de Hoy, 1999), 411.

${ }^{19}$ Preston, El Holocausto Español, 17.

${ }^{20}$ Aguilar makes this comparison with the dictatorships in the Southern Cone. P. Aguilar, 'The Spanish Amnesty Law of 1977 in Comparative Perspective: From a Law for Democracy to a Law for Impunity', in Amnesty in the Age of Human Rights Accountability, ed. F. Lessa and L. Payne (Cambridge: Cambridge University Press, 2012), 325-35. 
totalitarian regime. Repression ${ }^{21}$ included arbitrary arrests and executions, summary trials before military judges -with no guarantees and no right to appeal- that routinely imposed death sentences, imprisonment in inhumane conditions, ${ }^{22}$ labour camps, ${ }^{23}$ abolishment of the rights to association, meeting and expression, banning of political parties and trade unions, confiscation of properties belonging to pro-Republican groups and organizations, and persecution of all manifestations of political, religious and ideological dissidence. ${ }^{24}$ The Republic and its sympathisers, civil servants and ordinary citizens that had not enthusiastically supported the rebellion were criminalised. On this basis, from 1940 the Prosecutor of the Supreme Court was instructed to initiate the 'General Cause', to prosecute the crimes committed by what they named the 'red domination'. Through this legal and institutional system, the new regime became firmly established in the 'rule of law'.

${ }^{21}$ The cruellest years were right after the war, in 1939, and during what is commonly referred to as the 'triennium of terror' (1947-1949). After that period, there were less mass scale human rights violations, but persecution and torture was frequent. Towards the end of the regime, repression was more localised in regions with strong national identity.

${ }^{22}$ Comisión Interministerial para el estudio de la Situación de las Victimas de la Guerra Civil y del Franquismo, Informe General de la Comisión Interministerial para el estudio de la Situación de las Victimas de la Guerra Civil y del Franquismo, 28 July 2006, 77, available at Todos los Nombres, http://www.todoslosnombres.org/content/materiales/informegeneral-la-comision-interministerial-para-el-estudio-la-situacion-las (accessed September 10, 2016).

${ }^{23}$ L. Ríos Frutos, B. Martínez Silva, A. García-Rubio, and J. Jiménez, 'Muertes en Cautiverio en el Primer Franquismo: Exhumación del Cementerio del Penal de Valdenoceda (19381943)', Complutum 19 (2008): 141. The last camp, Los Merinales (Sevilla), closed only in 1962.

${ }^{24}$ See generally M. Ortiz Heras, 'Instrumentos legales del terror franquista', Historia del Presente 3 (2004): 219. 
An extensive process of purge reached all state institutions, including public and private companies. Whilst $80 \%$ of the jobs were reserved for those who had fought on the Franco side and friends of the so-called 'National Movement', most of the civil servants under the Republic were suspended. Of particular interest here was Francoism's co-option of the legal profession by purging anyone considered to be ideologically unreliable and only appointing sympathisers as the new judges, prosecutors and court staff.

The first years of Franco's regime saw an intensive activity of celebration and exaltation of those who had died in support of Franco and his rebellion. ${ }^{25}$ Their bodies were located, exhumed, identified and given burial. Their families were given special status and reparations schemes. Meanwhile, those killed in battle or assassinated by Franco's troops and his supporters remained in mass graves. ${ }^{26}$ Their families were not only deprived of any sort of compensation but suffered further repression, wherein they were marginalised and denied the economic means for a decent life. Many were forced to hide their condition as a victim and bury their own identity in silence as a survival mechanism. These victims of the civil war that remained ignored or vilified and their relatives and those who suffered the latter repression are the victims of our study (hereinafter, 'the victims').

25 J.M. Tamarit Sumalla, Historical Memory and Criminal Justice in Spain. A Case of Late Transitional Justice (Cambridge/Antwerp/Portland: Intersentia, 2013), 42. For initiatives to honour the fallen for Franco see L. Castro, 'El Recuerdo de los Caídos: Una Memoria Hemipléjica', Ebre 38. Revista Internacional de la Guerra Civil (1936-1939) 3 (2008): 17196.

${ }^{26}$ Gil Gil, La Justicia de Transición en España, 42. In a sinister symbolism of national reconciliation at the end of 1950s thousands of bodies of republican victims were taken to the Valley of the Fallen. 
The dictatorship's repression was based on a manipulation of history, the invention of memory and the self-imposed silence and censorship by the war's losers. The war was portrayed by the victors as inevitable given the political instability that preceded it during the last years of the II Republic. ${ }^{27}$ Franco's regime imposed an official discourse over its own victory as a 'Crusade' against communism to defend the Western Christian civilization. ${ }^{28}$ The episodes of the war were unequally narrated. The scale of Franco's army's violations were downgraded and even negated. ${ }^{29}$ On the contrary, the violence of the Republican army was exalted and given much centrality in the accounts of the war. ${ }^{30}$ This narrative sought the imposition of a collective memory of shared guilt and the saviour of the nation nature of Franco through symbolic exaltations of the regime -monuments, parades, street names, festivities- and indoctrination through school textbooks, news and documentaries, ${ }^{31}$ imposing over the population what Santos Juliá has called 'the rule of memory'. ${ }^{32}$ A historical and social account of the war as a fratricidal

${ }^{27}$ A. Reig Tapia, La cruzada de 1936. Mito y memoria (Madrid: Alianza Editorial, 2006), 97-104; Tamarit Sumalla, Historical Memory, 42-3.

${ }^{28}$ H.R. Southworth, El mito de la cruzada de Franco (Barcelona: DeBolsillo, 2008), 529-530. Among others, see an attempt to legally justify the rebellion as a crusade in $\mathrm{J}$. de la $\mathrm{C}$. Martínez, ¿Cruzada o rebelión? Estudio histórico-jurídico de la actual guerra de España (Zaragoza: Librería General, 1938), 209-10.

${ }^{29}$ Martínez, ¿Cruzada o rebelión?, 209-10.

${ }^{30}$ Historians have demonstrated how the narrative of the episodes of the war provided a bias account, based on myths and the manipulation of facts and figures. See generally En el Combate por la Historia. La República, la Guerra Civil y el Franquismo, ed. A. Viñas (Barcelona: Pasado y Presente, 2012).

${ }^{31}$ A. Reig Tapia, 'La Pervivencia de los Mitos Franquistas', in ibid., 909.

${ }^{32}$ S. Juliá, 'Bajo el Imperio de la Memoria', Revista de Occidente 302-303 (2006): 7-19. 
bloodbath was built and maintained throughout the dictatorship and the democratic transition. In this context, during the Franco years the defeated resorted to silence as a protective measure.

Jo Labanyi has argued that silence was not a consequence of the trauma, as has been explored in other post-conflict and post-violence situations, nor a failure of memory, but rather a conscious coping strategy chosen by the victims,${ }^{33}$ for their own survival and the protection of their loved ones. ${ }^{34}$ In trauma theory, silence is a consequence of an inner psychic process responsible for blocking catastrophic event or events' registration in consciousness. ${ }^{35}$ In this explanation the victim is unable to recall the traumatic event voluntarily (as Labanyi describes, 'this narrative turns survivors of traumatic events into victims of psychic processes they cannot control ${ }^{36}$ ), unlike in the case of Spain, where survivors chose not to recall. An important consequence of this is what Labanyi calls 'habits of silence' ${ }^{37}$ In Spain, difficulty to find words to articulate previously untold experiences is due to the habits of silence acquired over many years. Silence laid over the individual stories of the war losers and covered their collective history, and for four

33 J. Labanyi, 'The Languages of Silence: Historical Memory, Generational Transmission and Witnessing in Contemporary Spain', Journal of Romance Studies 9 (2009): 24.

${ }^{34}$ See for example the recollection of the forensic anthropologist Francisco Etxebarria, who has led many of the exhumations in Spain, on his mother's silence over her role as a nurse during the Civil War to 'protect him', in ibid., 23-4. This is a common occurrence in many Spanish homes.

${ }^{35}$ As Judith Herman puts it, '[t]raumatic memories lack verbal narrative and context'. J. Herman, Trauma and Recovery (New York: Basic Books, 1997), 38.

${ }^{36}$ Labanyi, 'The Languages of Silence', 24.

${ }^{37}$ Ibid. 
decades two generations of Spaniards learned to remain silent, whisper and look over their shoulder when talking. ${ }^{38}$

\section{Amnesty and the 'pact of silence' during the political transition to democracy}

The dictatorial regime established by Franco was, as such, never fully dismantled. His death marked the beginning of a transition towards democracy, which implied institutions, social structures and people adapted to the new political regime. ${ }^{39}$ Such institutions, structures and individuals in fact continued to rule political and social life and occupy the most prominent role in the new democratic system.

Whilst generally considered an example of a peaceful transition, this political process was not free from violence. ${ }^{40}$ As Aguilar has sustained, the Spanish transition cannot be understood without the consideration of a climate of persistent political violence. ${ }^{41}$ This, together with the prevailing traumatic memory of the political violence that preceded the civil war and the shared guilt over the atrocities which had been engraved in the population over forty years of propaganda and manipulation of historical

${ }^{38}$ As Ferrándiz points out, 'The screen of silence, fear and self-censorship has been particularly strong in local, rural contexts'. F. Ferrándiz, 'Cries and Whispers: Exhuming and Narrating Defeat in Spain Today', Journal of Spanish Cultural Studies 9 (2008): 177.

${ }^{39}$ During the transition, the most important rules of the new democratic system were adopted by consensus between the Francoist reformist and the moderate groups of the democratic opposition (Aguilar, 'The Spanish Amnesty Law of 1977', 318).

${ }^{40}$ See figures in Gil Gil, La Justicia de Transición en España, 45. The attempted coup d'état in 1981 evidences the fragility of the new-born democracy.

${ }^{41}$ Aguilar, 'The Spanish Amnesty Law of 1977', 318-22. 
facts, is instrumental in why democratic stability took precedence over all other objectives, including accountability for past crimes. ${ }^{42}$ The desire for democracy, economic development and integration in Europe or, in other words, the determination not to dwell on the past but instead 'to look forward' played a significant role in the adoption of a 'pact of silence' over crimes committed by Franco and his regime during and after the Civil War. ${ }^{43}$

Whilst this term of 'pact of silence' has been widely used and accepted by many authors, it is now becoming contested. Loureiro considers it a poor metaphor and states that the notion of a pact of silence calls to mind a conspiratorial vision of a bunch of politicians hatching agreements that subsequently have to be made to pervade the populace. According to him, such notion is grounded on an old-fashioned concept of power as an all-controlling force wielded by an elite, in which the populace is confined to a passive or merely reactive role. The transition, however, was characterized by a continuous give-and-take between power and resistance, with the many political and popular forces in action striving to reach a balance that would satisfy the majority. The constant strikes and popular demonstrations that caused a stream of steady concessions by Franco's heirs were precisely one of the transition's most notable features. To suppose that there was a pact of silence, Loureiro considers, is to fail to acknowledge that even a totalitarian regime could not have muzzled the politicians of various tendencies, nor the

${ }^{42}$ See generally P. Aguilar, Memory and Amnesia (Oxford: Berghahn Books, 2002), and P. Aguilar, Políticas de la Memoria y Memorias de la Política (Madrid: Alianza Editorial, 2008).

${ }^{43}$ Tamarit Sumalla, Historical Memory, 62. 
newspapers, independent publishers, novelists, workers, students, graphic artists or any other vehicle of public opinion. ${ }^{44}$

Whether we accept the argument that silence during the transition was a consequence of a tacit pact, 'pact of silence' or not, the reality is that Spain went through a social 'pact of forgetting'. The relationship between the roles of silence and forgetting ${ }^{45}$ is an important element to consider in the Spanish transition. During the debates to approve normative instruments to declare amnesty for those incarcerated by the regime there were recurrent references to the need to forget the past to focus on the present, by all political parties. ${ }^{46}$ The very first months and years that followed the death of the Dictator saw a profuse number of demonstrations, publications and debate on the past, the war and its consequences. There was voracity for knowledge and history in the population. ${ }^{47}$ However, the process of approval of the amnesty regulations, concluded by the first elected Parliament of the democracy, brought what Juliá has described as the first pact of the transition: 'a pact on the past that, ultimately, prevented it to be used as an

${ }^{44}$ Á.G. Loureiro, 'Pathetic Arguments', Journal of Spanish Cultural Studies 9 (2008): 225.

${ }^{45}$ We consider that terminology nuances are important in this point. Here we deliberately distinguish the use of forgetting and oblivion to highlight the difference between the Spanish olvidar as a conscious or unconscious process and olvido as a place where things that have been forgotten remain.

${ }^{46}$ See for example the analysis of the political negotiations and normative proposals in S. Juliá, Elogio de la Historia en Tiempos de Memoria (Madrid: Marcial Pons, 2011), 19-41. In fact, Julia demonstrates that the Communist Party had appealed to general amnesties, for winners and losers of the war, since 1959, calling for national reconciliation and avoidance of revenge.

${ }^{47}$ Ibid., 24-8. 
instrument in the political fights of the present. ${ }^{48}$ Whether we can describe this as a pact of silence or a pact to forget is debatable, but ultimately it brought a sidelining of legitimate claims for justice, what others have tagged as oblivion or amnesia. ${ }^{49}$ And these -forgetting, silence and ultimately oblivion- led to impunity, as we will argue later. For, as far as victims were concerned, this pact involved they would be silent about the crimes committed during the Civil War and the Dictatorship by Franco's regime.

It was during this period of transition that a legal architecture, the cornerstone of which is the 1977 Amnesty Law, to provide continued impunity for the crimes committed during the civil war as well as during the Franco dictatorship was established. Amnesty's main aim was to benefit those convicted of political crimes because of their opposition to Franco's regime. It had widespread social backing and was overwhelmingly supported by the democratic political parties. Amnesty was presented as a milestone in the reparation and the rehabilitation process of those punished or discriminated for political reasons during the Franco years. In addition, amnesty was justified as a tool to prepare the country as a whole for shared life and reconciliation, repairing the wrongs of the past and allowing society to forget and concentrate on the future. But the Amnesty Law also contained two provisions that effectively guaranteed impunity for the crimes committed by Franco's regime. One disposition established amnesty for the crimes committed by the authorities and public order agents when investigating and prosecuting political crimes (Article 2.e), whilst the other contained a general clause of amnesty for crimes committed

\footnotetext{
${ }^{48}$ Ibid., 39.
}

49 See among many others A. Gil Gil, 'Spain as an example of total oblivion with partial rehabilitation', in The Role of Courts in Transitional Justice. Voices from Latin America and Spain, ed. J. Almqvist \& C. Espósito (Routledge: London and New York, 2012), 126. 
by civil servants and agents of the public order against the enjoyment of human rights (Article 2.f.). It is important to note that the Amnesty Law is a pre-constitutional norm the Constitution was approved by popular referendum in $1978,-^{50}$ which has not only not been repealed, but has been repeatedly invoked. While politicians refer to it to appeal to a sort of 'spirit of reconciliation', the judiciary has used it to prevent any judicial review of the thousands of crimes committed during the nearly forty years of repression. This has been particularly salient in the latter attempts to search for justice, analysed below.

Few other measures to address the past regime and dismantle its institutional and legal architecture were adopted in the early years of the transition. Francoist symbolism remained. Restorative measures slowly began in the 1980s, but they were not undertaken as part of a comprehensive scheme of reparation, let alone in the framework of a wider policy of transitional justice. ${ }^{51}$ As a direct consequence of the nature of a transition made from within, where there was no abrupt ideological or personnel break with the previous system, ${ }^{52}$ there was no institutional reform for the vetting of former public officials in

${ }^{50}$ The Amnesty Law was the first law adopted by the first democratically elected parliament and the last of the instruments used from 25 November 1975 to provide pardons and amnesty for political crimes. The law was approved by the mayority of congress (296 votes in favour, 18 abstentions, 2 votes opposed and 1 invalid vote, see Congreso de los Diputados, Constituent Term, Plenary Session No. 11, 14 October 1977, Diario de Sesiones 24, 974). The abstention came from Alianza Popular, the right-wing party mainly composed by those who had held important positions during the dictatorship, latter transformed in today's Partido Popular (Aguilar, 'The Spanish Amnesty Law of 1977’, 318).

${ }^{51}$ For a comprehensive list of legal instruments adopted between 1976 and 1999 establishing these and other measures, see Gil Gil, La Justicia de Transición en España, 57-72.

${ }^{52}$ See A. Aragoneses, 'Continuidad y Discontinuidad del Pasado en la Justicia del Presente', in F. Fernández-Crehuet López and D.J. García López, Derecho, memoria histórica y dictaduras (Granada: Comares, Granada, 2009), 61-78. 
civil and military institutions in influential positions. The exit from public and official life of those closer to Franco's regime was facilitated mainly through a progressive succession of early retirements among the military and judicial personnel. More often than not, however, political, military and religious elites continued to occupy important spheres of public life, including in the army, the police and -most important here- the judiciary.

There was little attempt to seek accountability during these first decades of democracy. The limited claims for justice were immediately tagged as revanchist (motivated by revenge) not only by the right wing parties, but by groups throughout the whole political spectrum. The official narrative was that Spanish society overwhelmingly backed the forward looking move; however these political decisions had a direct impact on victims' legitimate rights to truth, justice and reparation. Not only were victims never consulted, but the democratic pact also sealed some of their options for the exercise of such rights. Ultimately, the social pact of silence facilitated democracy at the expense of justice, the restoration of rights and dignity of a segment of the population.

\section{Exhumations and the defiance of the silence}

It was not until a group of private citizens undertook a series of privately led exhumations'searching for the dead'- that a process of revisiting the past and defying the silence that had surrounded the individual stories of many of the victims of the war started. Since then, thousands of bodies have been exhumed, all thanks to the work of private groups 
and individuals, on occasion at their own expense, and with no official sanction. ${ }^{53}$ This movement is sustained not only by those who directly suffered repression but mainly by their grandchildren (born at the end of the dictatorship or early years of the transition), who struggle to understand what happened to the lost members of their families, whose names and stories were buried in silence while they were growing up. The absence of the second generation, or rather their limited role as spectators, is directly related to the imposed silence during the dictatorship to which we referred above. ${ }^{54}$ However, the process of opening the graves encouraged victims along with their surviving relatives to talk and their grandchildren to listen. ${ }^{55}$ Thus silence was defied.

${ }^{53}$ Between 2000 and 2014, over seven thousand exhumations had taken place. See F. Etxeberria, Exhumaciones llevadas a cabo en España desde el año 2000 (actualizado diciembre 2014) (Universidad del País Vasco, Ministerio de la Presidencia and Sociedad de Ciencias Aranzadi, 2004), available at Políticas de la Memoria, http://www.politicasdelamemoria.org/wp-content/uploads/2010/10/Exhumacionesllevadas-a-cabo-en-Espa\%C3\%B1a-2000-2014.pdf (accessed September 10, 2016).

${ }^{54}$ Labanyi, 'The Languages of Silence', 25. There are of course examples of second-generation people (born in the late 1950s) who chose to break the silence that their parents maintained, sometimes until their deaths. Labanyi suggests this was done out of a retrospective sense of guilt at having done nothing to alleviate their parents' suffering under the dictatorship. The silence of the second generation has received practically no attention from scholars.

55 The exhumations of mass graves have encouraged victims' relatives to talk. Ferrándiz has suggested that the difficulties that victim's relatives find in articulating previously untold experiences is due not to a blocking or failure of memory, but to the habits of silence acquired over so many years. In other cases, people talking for the first time about what they suffered in and after the war, the capacity for detail recollection is extraordinary. F. Ferrándiz, 'The Return of Civil War Ghosts: The Ethnography of Exhumations in Contemporary Spain', Anthropology Today 22, no. 3 (2006): 7-12. 
The reaction of the grandchildren generation against their elders' silence was crucial in igniting and driving a process that started with the search for bodies. ${ }^{56}$ This socalled process of 'recovery of historical memory ${ }^{57}$ has been a process of breaking through the use of history by Franco's regime to create an 'official memory' about the time that preceded the civil war, the conflict and the collective guilt over it reflected in the long silence which preceded the transition and was ultimately consolidated by the search for amnesty (and, subsequently, amnesia). As argued before, the victims on Franco's side were key to this memory, their worship being a core element to this construction. ${ }^{58}$ Recovering historical memory has also meant attempting to break through the pact of silence during the transition, allowing for a new narrative of consensus over the generalised choice of silence to settle, ${ }^{59}$ thus contributing to a renewed process of negotiation over a new shared collective memory. Therefore, memory originally appeared as a substitute of justice, which in the beginning of this process did not seem a feasible option, as we will argue later. However, overall, the claim has drifted to a broader process

${ }^{56}$ Labanyi, 'The Languages of Silence', 25.

${ }^{57}$ As Labanyi noted, this expression is problematic in that it supposes that memory lies buried in the past, awaiting 'disinterment' (ibid). However, the phrase has caught on; the archaeological metaphor is seductive in its promise to offer access to a lost past. It similarly suggests that memory bypasses representation by giving us a 'piece' of the past, like the human remains being recovered.

${ }^{58}$ Castro, 'El Recuerdo de los Caídos', 165. Junquera even asserts that historical memory was an invention of Franco. N. Junquera, 'Lo que Ocurre en las Fosas del Franquismo', in Memoria histórica, J.S. Pérez Garzón and E. Manzano Moreno (Madrid: Catarata, 2010), 16-7.

59 S. Gálvez Biesca, 'Las víctimas y la batalla por el derecho a la memoria: la Comisión interministerial para el estudio de la situación de las víctimas de la Guerra Civil y el franquismo', Mientras tanto 97 (2005): 35-6. 
of transitional justice that never took place in Spain in a comprehensive way, ${ }^{60}$ including not only the search for truth, but also for justice and reparation.

The beginning of the exhumation process led to an intensification of political pressure to open public debate over the past that ultimately materialised in the 2007 Law for the recognition and broadening of rights and establishment of measures in favor of those who suffered persecution or violence during the civil war and the Dictatorship, ${ }^{61}$ also known as the Ley de Memoria Histórica (Historical Memory Law, hereinafter HML). Thirty years after the transition, the HML is firmly grounded on the consensus to look forward narrative -in its own wording, in the spirit of reconciliation and concord that had inspired the transition. ${ }^{62}$ In spite of the ambitious set of aims directed both to victims and the wider citizenship laid out in its preamble, its text and the institutional responses have fallen short. The measures are not based on the recognition of the existence of violations of human rights, but rather on some kind of compensatory or equating mechanism. ${ }^{63}$ The

${ }^{60}$ J. Álvarez Junco, 'La memoria histórica española', X Cursos de Derechos Humanos de Donostia-San Sebastián (2009): 44-5; M. Capellá i Roig, 'La recuperación de la memoria histórica desde la perspectiva jurídica e internacional', Entelequia. Revista Interdisciplinar 7 (2008): 273-9.

${ }^{61}$ Ley 52/2007 por la que se reconocen y amplían derechos y se establecen medidas en favor de quienes padecieron persecución o violencia durante la guerra civil y la dictadura, 26 December 2007.

${ }^{62}$ HML, Preamble.

${ }^{63}$ Gil Gil, La Justicia de Transición en España, 97; J. Chinchón Álvarez, 'El Viaje a Ninguna Parte: Memoria, Leyes, Historia y Olvido Sobre la Guerra Civil y el Pasado Autoritario de España. Un Examen desde el Derecho Internacional', Revista del Instituto Interamericano de Derechos Humanos 45 (2007): 181-3. 
law does not attempt to restore the victims' right to justice nor to confront the residual presence of the imposed memory.

In terms of justice -an absent idea in the HML-,${ }^{64}$ it merely rejects the legitimacy both of courts, juries and other criminal or administrative bodies established during the Civil War in order to sentence or penalise persons on political, ideological or religious belief grounds, and their decisions. ${ }^{65}$ Sentences and fines passed on political, ideological or belief grounds by courts or criminal and administrative bodies during the Dictatorship against those defending the previous regime or the reestablishment of democracy, or following a way of life in accordance with current constitutional rights are similarly declared illegitimate, a claim still sought by the victims. But it does not declare such decisions illegal or null and void. By the same token, it implicitly endorses the Amnesty Law by not declaring it repealed. Therefore, it maintains the rule of impunity and the lack of officially-sponsored investigation of the facts. Accountability is not to be expected under its umbrella.

Instead, the possibility to make justice as a core element of transition to democracy has been abandoned to focus on the so-called 'historical memory'. Nevertheless, in terms of truth and memory, it just seeks to promote recuperation of the personal memory of those who suffered persecution and violence. With a timid acknowledgement of the victims' and their relatives' right to remember and recover their

${ }^{64}$ In Druliolle's opinion, '[t]he lack of reference to the idea of justice, not simply reparation, is [...] striking'. V. Druliolle, 'Recovering Historical Memory: A Struggle against Silence and Forgetting? The Politics of Victimhood in Spain', International Journal of Transitional Justice 9, no. 2 (2015): 326.

${ }^{65}$ Article 3.1 HML. 
story, the state merely guarantees a right to talk without shame and fear, which they had not openly enjoyed until now. However, it does not ensure that their stories enter the public domain in order to confront Francoist historical memory nor the official discourse of reconciliation built during the Transition. No officially-endorsed truth commission or report concerning the events in the civil war and under Franco's ruling is considered. No public policy on memory is designed, either.

\section{"What do they want? For us to wait 75 more years?"}

In the above-described context, it is not surprising that victims tried to find a public forum to tell their stories. They attempted to use the courtroom as a space to defy silence. In 2006 claims reached the Juzgado Central de Instrucción (Central Investigating Court) of the national court Audiencia Nacional, including that of the Platform of Victims of Enforced Disappearances by Francoism, which demanded a judicial investigation of the thousands of enforced disappearances.

In 2008 Central Investigating Judge, Baltasar Garzón, accepted his jurisdiction over alleged crimes, which included illegal detention without news of fate (enforced disappearances) committed in the context of crimes against humanity between 1936 and 1951. ${ }^{66}$ The judicial decision explicitly established that the inexistence of persons direct or indirectly responsible for the crimes does not prevent the need to provide victims with

${ }^{66}$ Juzgado Central de Instrucción No. 5, Audiencia Nacional, Diligencias Previas Proc. Abreviado 399/2006 V, Auto, 16 October 2008. 
protection. ${ }^{67}$ Judge Garzón's ruling established that exhumations were outside the competence of his central court, but instead required the cooperation of the courts with territorial jurisdiction over the places where graves were located. Consequently, the decision ordered the opening of necessary legal procedures to satisfy the claimants' demands to find each 'disappeared' listed in the claim. While some local courts assumed the delegated competence to order the exhumations at local level, most refused to do so on the basis of either the Amnesty Law or the applicability of statutory limitations to the alleged crimes.

The recourse to the courts evidences a desperate attempt for victims to exercise their right to justice in order to seek truth, institutional support in their search for their relatives and an official endorsement of their attempts to challenge the imposed version of events through the courts. No material reparation (besides the restitution of the remains to the families) was sought. Neither was individual criminal accountability. ${ }^{68}$ On the

${ }^{67}$ Ibid., section XIII. The decision names a series of high-level perpetrators, including Franco, as responsible for the crimes, and demands the public authorities to provide death certificates to certify the extinction of individual criminal responsibility.

${ }^{68}$ J. Chinchón Álvarez, 'Examen del Auto del Juzgado de Instrucción No 5 de la Audiencia Nacional por el que se acepta la competencia para investigar los crímenes contra la humanidad cometidos en la Guerra Civil y el franquismo', La Ley 5 (2008), 1388. 
contrary, both in the judicial claims ${ }^{69}$ and in Judge Garzón's ruling ${ }^{70}$ there was a clear intention to relinquish such accountability. Ultimately, the search for truth drove forward a search for justice. A justice that did not seem feasible up to that point, preventing victims from resorting to the judiciary, for a number of reasons that we will argue lately.

Judge Garzon's decision was acclaimed by victims but met with fierce criticism from the right wing of the political spectrum, including many in the judiciary. In 2008, after the General Prosecutor appealed Judge Garzon's ruling, the Criminal Chamber of the Audiencia Nacional ruled the court incompetent to continue the case and closed the judicial avenue for victims. ${ }^{71}$ Following this, two right wing organisations initiated legal proceedings in the Supreme Court against Garzon, accusing him that by assuming jurisdiction over the disappearances he had knowingly issued an unjust decision. This is a crime under the Spanish Criminal Code. ${ }^{72}$ Both claims were later dismissed. Although

${ }^{69}$ Later, during the trial against Garzón (see later in this section), victims' relatives would declare that, even knowing who had perpetrated the crimes, all they wanted was to recuperate their relatives' remains. See e.g., their statements in M. Batallas, 'Dos víctimas de Franco subrayan ante el Supremo que su objetivo es recuperar a sus familiares', El Periódico, February 13, 2012, http://www.elperiodico.com/es/noticias/politica/tribunal-supremocomienza-oir-testimonio-victimas-franco-1375261, and N. Junquera, 'Sé hasta la matrícula del verdugo. Lo que quiero es a mi madre', El País, February 6, 2012, http://politica.elpais.com/politica/2012/02/06/actualidad/1328554737_164022.html.

${ }^{70}$ The direct perpetrators were not identified and individualised. Only Franco and the members of his government and other public institutions - all dead - were named responsible for the crimes under investigation.

${ }^{71}$ Audiencia Nacional, Pleno de la Sala de lo Penal, Procedimiento ordinario No. 53/08 del Juzgado Central de Instrucción No. 5, Expediente 34/08, Auto, 2 December 2008.

${ }^{72}$ The Supreme Court decision to accept jurisdiction over the claims has been severely criticised at political level but also considered unsustainable from a legal point of view, see J. Chinchón and L. Vicente, 'La investigación de los crímenes cometidos en la guerra civil y 
the Supreme Court established that the Judge was not criminally responsible, it insisted that Garzón had acted wrongly, as the Amnesty Law and the rules on prescription govern. ${ }^{73}$ Ironically, the only opportunity that victims have had to have their voices heard before a court in the judicial process against Garzon. On $1^{\text {st }}$ February 2012, Maria Martin, 81 years old at the time, was the first victim to declare before the Supreme Court. After declaring on the disappearance of her mother she declared to the media that she was still waiting for her to be exhumed and if she could she would have digged her up with her own nails. She asked "What do they want? For us to wait 75 more years?"74.

The path to justice closed at the domestic level, the victims resorted to the European Court of Human Rights (hereinafter ECtHR). Nonetheless, the result was equally deceiving. In 2012, a chamber of the ECtHR adopted an inadmissibility decision in the first case discussed therein, Antonio Gutiérrez Dorado and Carmen Dorado Ortiz against Spain. ${ }^{75}$ The applicants, Antonio Gutiérrez Dorado and Carmen Dorado Ortiz (who died in 2010, before the decision was issued), were grandson and daughter respectively to Luis Dorado Luque, a Member of the Spanish Parliament belonging to the socialist party that had been forcibly taken away on 18 July 1936 by military forces in

el Franquismo como delito de prevaricación. Análisis crítico del auto del Tribunal Supremo de 3 de Febrero de 2010 desde la perspectiva del derecho internacional', Revista Electrónica de Estudios Internacionales 19 (2010): 1-42.

${ }^{73}$ Tribunal Supremo, Sala de lo Penal, Sentencia No. 101/2012, 27 February 2012, legal ground 6, para. 3 .

${ }^{74}$ Obituary. Maria Martin, una ancina ante las togas, El Pais, 26 July 2014. Maria Martin died at the age of 83 , still waiting for her mother's body to be exhumed from the mass grave where she lies. [author's translation]

${ }^{75}$ ECtHR (3rd Section), Antonio Gutierrez Dorado and Carmen Dorado Ortiz v. Spain, Application no. 30141/09, Decision, 27 March 2012. 
circumstances that have not yet been fully established. The applicants had no reliable information as to their relative's fate after 28 July 1936. In early August 1936 the body of a person who according to the autopsy had died as a result of firearm injuries with serious wounds to the brain and liver was discovered with documents with Dorado Luque's name in his pockets. Initially registered as Dorado Luque in the civil registry, some days later the judge decided that there was not enough evidence regarding his identity, so they made a new entry in the civil registry was made stating the body was that of an 'unknown man'. In 1981 her widow initiated a procedure for 'voluntary declaration of death,' which would entitle her to widow's benefits. In 1993 a court confirmed that Mr Dorado Luque had disappeared and that his fate and whereabouts were unknown and ordered that his death (established on 30 July 1936) be recorded in the civil registry books. In May 2006 Carmen Dorado brought a criminal complaint that was dismissed on the basis of statutory limitations. The appeal court and the Constitutional Court confirmed the initial decision. Ms Dorado was among the applicants which, in December 2006, filed the complaint before the Audiencia Nacional, on which the decision on lack of jurisdiction was issued in 2008.

In their application before the ECtHR, the applicants - Antonio Gutiérrez Dorado and Carmen Dorado Ortiz -invoked Articles 2 (right to life), 3 (prohibition of torture, and inhuman or degrading treatment or punishment), 5 (right to liberty and security), 8 (right to private and family life) and 13 (right for an effective remedy before national authorities for violations of rights under the European Convention on Human Rights. Focusing on the enforced disappearance of Mr. Dorado Luque, the ECtHR considered that the applicants had waited too long before bringing their application. According to the Court, they should have introduced their complaints without undue delay once it had become 
apparent that the mechanisms provided by the State no longer offered 'any realistic hope of progress in either finding the body or accounting for the fate of their missing relative in the near future' ${ }^{76}$ Thus, based on a very strict application of the principle of due diligence in reaching the court, the ECtHR declared the complaint inadmissible. The Court did not take into consideration how the specific social circumstances and, very centrally the veil of silence and legacy of the repression, had determined the victims' behaviour, limiting their agency and ultimately their capacity of diligence.

\section{The Impact of Silence on the Right to Justice in Spain}

Silence, both as a surviving strategy and a transitional pact, has had a negative impact on Franco victims' right to justice. In the Spanish case, both dimensions intertwine and gather, and have ultimately resulted in systematic lack of accountability and impunity for crimes committed during the civil war and the dictatorship.

As a surviving strategy, silence is indeed disempowering. Martínez de Bringas has sustained -referring to memory- that the time of repression and silence plays against the time of memory. The time of the victim is never the time of the repression, in fact there is an inversely proportional relation among them. ${ }^{77}$ The same applies when considering justice. Martínez de Bringas continues saying that "what gets destroyed with spasmodic brevity is difficult to reconstruct with the circumstantial and utilitarian

\footnotetext{
${ }^{76}$ Ibid., para. 39.

${ }^{77}$ A. Martínez de Bringas, 'De la ausencia de recuerdos y otros olvidos intencionados. Una lectura política de los secuestros de la memoria', in El Derecho a la Memoria, ed. F. Gómez Isa (Bilbao: Universidad de Deusto, 2006), 269. [author's translation]
} 
allocations of postmodern democracies'. ${ }^{78}$ An additional element to take into consideration is the incapacity and inexperience of 'the repressed' to be activate democratic processes. ${ }^{79}$ Forty years of dictatorship is too long a time for a population to be quickly trained in a democratic modus operandi and to have a culture of democracy overnight. Furthermore, exile, repression and victimisation pose obstacles to the processes that lead to equality and justice.

Even when victims finally felt empowered once silence was symbolically broken through the exhumation processes, structural obstacles remained, anchored on the transitional pact founded on victims' silence. Regarding the existence of a proper judicial system as a key element to ensure the right to justice, the lack of vetting and institutional reform of the judiciary during the transition made the courts hostile and ultimately inaccessible to any justice demand. ${ }^{80}$ This is particularly true regarding the judges sitting at the Supreme Court. As Aragoneses has shown, judges that had been loyal to Franco's regime kept their positions in the higher ordinary tribunal in Spain, in opposition to the Constitutional Court, an extraordinary judicial body created by the 1978 Constitution. ${ }^{81}$

${ }^{78}$ Ibid.

${ }^{79}$ Ibid.

${ }^{80}$ As Aguilar sustains ' $[t]$ he existence of a very conservative judiciary in Spain is crucial to understand a key obstacle to truth and justice'. Aguilar, 'The Spanish Amnesty Law of 1977', 331. For a detailed account of the lack of reform and obstructionism of the judiciary see C. Jiménez Villarejo and A. Doñate Martín, Jueces, pero parciales. La pervivencia del franquismo en el poder judicial (Barcelona: Pasado y Presente, 2012).

81 A. Aragoneses, 'El Derecho Bajo el Franquismo. Transformaciones del Sistema Jurídico Español (1936-1978)', in Represión política, justicia y reparación. La memoria histórica en perspectiva jurídica (1936-2008), co-ord. M. Capellà and D. Ginard (Palma: Plural, 2009), 123-59. 
The continuation of most of the judiciary is a consequence of the transitional pact, which effectively traded the maintenance of many of the old structures for amnesty for political crimes and a constitutional regime.

As far as the existence of truly effective remedies before courts, the current ones are in no way effective. The continuous invocation of the Amnesty Law as well as statutory limitations to dismiss claims regarding crimes committed under Franco's rule demonstrate the limitations of the system. This is particularly true when it comes to enforced disappearances, a serious violation of human rights of a permanent character until the fate of the disappeared person is established. Therefore, in international law no statutory limitations apply before that moment. Instead, Spanish courts systematically take for granted that the disappeared are dead, without further investigation, thus violating fundamental human rights.

Turning back to the Amnesty Law, two points need to be highlighted. First, amnesty, as already mentioned, principally covered acts committed with a political intention. Only those that had been punished for political crimes benefited from the amnesty. Other victims that did not qualify as political criminals -such as the relatives of those executed during the Civil War and the Dictatorship or other groups persecuted for social reason, e.g. homosexuals- were not to expect any acknowledgment of their victimhood because of the amnesty. In general, nor were any victim of crimes committed by Franco's public forces (e.g. torture, rape), as public officers also benefitted from amnesty. Instead, Franco's victims were expected to contribute to the transitional pact by remaining silent and forgetting. Otherwise said, the imposition of silence. Not accepting 
this part of the pact, meant risking accusations of wanting revenge and obstructing the political path to democracy.

Secondly, the fact that the 1977 Amnesty Law is a pre-constitutional norm. The 1978 Constitution includes a broad set of fundamental rights -among them, the right to effective judicial protection- in line with international standards on human rights, as well as a general repealing provision. According to it, 'any provisions contrary to those contained in the Constitution are [...] repealed' ${ }^{82}$ A law limiting the right to effective judicial protection should, easily, be considered unconstitutional. Therefore, at any point any court facing the potential application of the Amnesty Law could simply decide not to apply it for that reason. Instead, Spanish courts have kept considering it as fully in force.

However, the impact of the pact of silence on the quest for justice regarding crimes committed under Franco's rule has allegedly been much more far-reaching than the Amnesty Law itself, at least until 2000. This argument is supported by the Enrique Ruano case, the only case of police brutality during the dictatorship tried up to date. It involved the torture and murder of Enrique Ruano, a student and member of an opposing political group, when he was under police custody in 1969. His family got his case re-opened in 1994. Although in 1996 the alleged perpetrators were acquitted due to lack of evidence allegedly manipulated by the police-, they sat in the dock without the Amnesty Law being applied; nor did the Supreme Court mentioned it when it confirmed the acquittal in 1997. This case shows that the invocation of the Amnesty Law is a recent trend, as courts did not consider it in the 90's. At the same time, one should wonder why if Ruano's relatives

\footnotetext{
${ }^{82}$ Spanish Constitution, Repeals, para. 3.
} 
succeeded in having the case re-opened (news that the national media widely reported on at that time), no other families attempted to follow the same path. Possibly, many felt that it was too late for that and there was no hope, as the ECtHR would put it. It is a fact too that they did not attempt to reach international human rights courts. However, the eagerness to bring criminal complaints in mid-2000 points in a different direction. By that time, the crimes victims had suffered were no longer a taboo. Therefore, there are obvious indications that the pact of silence, the prevailing fear and lack of empowerment of victims all contributed to the lack of attempts to seek justice through courts.

In fact, it is symptomatic that efforts to get justice done have not stopped in recent years. On the contrary, victims are looking for other for where to achieve their goal. The most remarkable one was the complaint filed in 2010 in Argentina by several victims of crimes committed since the beginning of the Civil War until the first democratic elections in 1977 (including enforced disappearances and tortures). ${ }^{83}$ The goal now is still to seek truth, but also justice and accountability. ${ }^{84}$ The Argentinian judge admitted the complaint and, although Spain has so far refused to extradite the alleged perpetrators, her decisions have already had an important effect: on the $19^{\text {th }}$ January 2016 took place the opening of the first mass grave under the authorisation of a Spanish judge, following a request of

${ }^{83}$ Querella 4591/2010, nominada 'N.N. por genocidio y/o crímenes de lesa humanidad cometidos en España por la dictadura franquista entre el 17 de julio de 1936, comienzo del golpe cívico militar, y el 15 de junio de 1977, fecha de celebración de las primeras elecciones democráticas'.

${ }^{84}$ C. Slepoy, 'Querella argentina. Una historia de ida y vuelta', Coordinadora estatal de apoyo a la Querella Argentina contra crímenes del franquismo, http://www.ceaqua.org/querellaargentina/ (accessed September 10, 2016). Carlos Slepoy is the legal representative of the victims that have filled the complaint. 
international cooperation issued by the Argentinian judge. This could be the beginning of a process where the quest for justice finally provides also with truth.

\section{Conclusions}

The transitional experience in Spain shows how strongly silence (whether explicit or implicitly imposed) can affect victims' right to justice as expected in a mature democracy, leading to an obvious result: impunity. Silence about Franco's crimes was first adopted by victims as a strategy to survive in a regime that built a memory of the events where they had no place. Attempts to contest the official version of the Civil War and oppose the dictatorial regime would result in repression and further victimisation. Silence was therefore their only way to resist four decades of dictatorship without further damage. The transitional process in the late 70s imposed them a second layer of silence, insofar they did not get public spaces to tell their stories and have their suffering acknowledge. On the contrary, the pact to forget and move forward forged at the political level to facilitate a fresh start of the new democratic era became a pact of silence. Amnesty was granted to political crimes, but also to public agents who had committed gross violations of human rights. The victims, far away from being political criminals, had to accept not putting forward their claims for justice. The Amnesty Law sacrificed their rights to justice, truth and reparation for the sake of political stability. They got nothing in exchange, and had yet to learn to use a the tools provided by democracy, except that even then they faced a judicial system which was largely a continuation of Franco's courts which would not provide effective remedies against past human rights violations.

Altogether, forty years of silence, the transitional pact, amnesty, fear and disempowerment refrained the victims from making their claims. The turning point came 
in the 2000s, when the third generation (grandchildren, grandnephews and grandnieces), feeling the urge to know the details about their relatives' fate and to restore their stories into the collective memory, started opening the mass graves where the latter were buried. Through private initiatives, victims' associations (literally) disinterred the past and drew back the veil of silence over Franco's crimes.

In an attempt to find a public forum to tell their stories and seek the truth, victims resorted to courts, but it was fruitless. Both at domestic courts and at the ECHR have their claims been dismissed. Remarkably enough, the latter has based its decision not to admit complaints regarding Franco's crimes on the lack of diligence of victims, without even considering their lack of agency brought about by decades of imposed silence and repression. This deserves strong criticism. Courts should take into consideration the impact of such contextual elements on victims' real capacity to claim their rights, if they are to provide fora to effectively fight against impunity.

Nevertheless, what in the beginning was a truth-seeking strategy has become a justice-seeking process. Aware of the fact that the Spanish judicial system lacks key elements to guarantee their right to justice, namely the proper functioning of the judicial system and the existence of truly effective remedies before courts, they brought a claim before an Argentinian court in order to get crimes investigated and punished. Paradoxically, the first effect of this new attempt has been a bit of truth, finally unburied from a mass grave. 